\title{
ПСИХОЛОГІЧНИЙ СУПРОВІД ДІТЕЙ З ОСОБЛИВИМИ ОСВІТНІМИ ПОТРЕБАМИ: СТРАТЕГІЯ РЕАЛІЗАЦІї
}

https://doi.org/10.37472/2707-305X-2020-2-1-7-5

\author{
ПРОХОРЕНКО Леся Іванівна \\ доктор психологічних наук, \\ старший науковий \\ співробітник, заступник \\ директора з науково- \\ експериментальної роботи \\ Iнституту спеціальної \\ педагогіки і психології імені \\ Миколи Ярмаченка \\ Начіональної академії \\ педагогічних наук України, \\ м. Київ, Україна

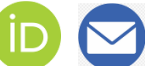

\section{БАБЯК Ольга Олексіївна} кандидат психологічних наук, завідувач відділу психологопедагогічного супроводу dimeй з особливими потребами Iнституmу спеціальної педагогіки і психології імені Миколи Ярмаченка Національної академії педагогічних наук України, м. Київ, Україна

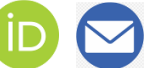

\section{БАТАШЕВА Наталія Іванівна кандидат психологічних наук, вчений секретар Iнституmy спеціальної педагогіки i психології імені Миколи Ярмаченка Начіональної академії педагогічних наук україни, м. Київ, Україна}

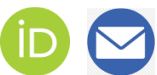

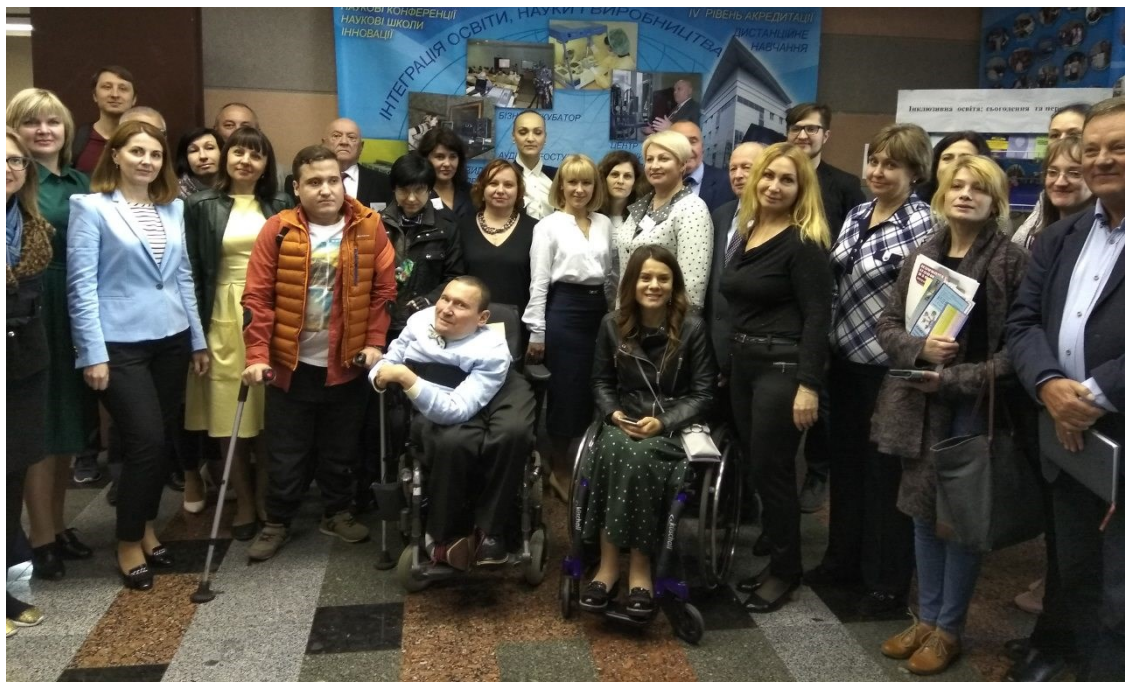

Анотачія. у статmі розкрито особливості психологічної допомоги дітям з особливими освітніми потребами, окреслено складові ефективності психологічного супроводу та основні напрями діяльності. Звернуто увагу на діагностичну, консультативну та корекційну роботу в процесі навчання, соціалізації і життедіяльності таких осіб. Мета статmі полягає у визначенні стратегії психологічного супроводу дітей з особливими освітніми потребами, їхніх родин і формулюванні напрямів роботи. Обгрунтовано, що психологічний супровід дітей із особливими освітніми потребами є пролонгованим, динамічним процесом, цілісною діяльністю психологічної служби освітнього закладу, яка складається з таких взаємопов'язаних компонентів: систематична психологічна допомога дітям з особливими потребами у вигляді консультування, психокорекиії, психологічної підтримки; психологічна допомога батькам, які виховують таких дітей; моніторинг психолого-педагогічного та соціального статусу дитини в динаміці ї психічного розвитку; організація життєдіяльності дітей із особливими потребами у соціумі з урахуванням їх психічних $i$ фізичних можливостей. Ефективним вирішенням цих питань є залучення дітей з особливими потребами в інклюзивне освітнє середовище, що передбачає створення спеціальних умов для задоволення їхніх освітніх потреб (організаційно-методичних, психолого-педагогічних, корекційно-розвивальних та ін.) у навчанні та соціалізації. Відповідно зміст і складові психологічного супроводу $\epsilon$ змістово-організаційною основою психолого-педагогічної роботи з дитиною з особливими освітніми потребами в процесі навчання та життєдіяльності, що дасть змогу забезпечити індивідуальний прогрес кожної дитини впродовж життя.

Ключові слова: психологія; психолого-педагогічна підтримка; корекційна робота; консультування; особливі освітні потреби.

В умовах реформування системи освіти в Україні посилена увага приділяється проблемам виховання і розвитку дітей із особливими потребами. Це стосується й питання щодо формування загальної 
компетентності особистості як системи окремих компетенцій, знань і необхідного для ії результативної діяльності в соціумі досвіду. Уведення в дію нового Закону України «Про освіту» (2017) закріплює практику надання особам з особливими освітніми потребами «системи освітніх послуг, гарантованих державою, що базується на принципах недискримінації, врахування багатоманітності людини, ефективного залучення та включення до освітнього процесу всіх його учасників», що гарантує їм право на освіту й забезпечення рівних можливостей у всіх сферах суспільного життя.

У низці урядових нормативно-правових документів , зокрема постановах Кабінету Міністрів України «Про затвердження Положення про інклюзивно-ресурсний центр» (2017), «Деякі питання створення ресурсних центрів підтримки інклюзивної освіти та інклюзивно-ресурсних центрів» (2018) і наказах МОН України «Про затвердження концепції розвитку інклюзивного навчання» (2010), «Про затвердження Примірного положення про команду психологопедагогічного супроводу дитини з особливими освітніми потребами в закладі загальної середньої та дошкільної освіти» (2018) тощо, лежить базове розуміння єдиної загальнодержавної стратегії реформування галузі освіти. Вона базується на тому, що кожна дитина має унікальні особливості, інтереси, здібності та навчальні потреби і, відповідно, система освіти має створюватися у напрямі «школи для всіх», де діти 3 особливими освітніми потребами зможуть реалізувати своє право на освіту (Кабінет Міністрів України, 2017; МОН України, 2018). Однією із ключових ідей втілення стратегії створення сучасного освітнього середовища для дітей 3 особливими потребами $€$ переорієнтація на інклюзивний підхід на засадах інклюзивних цінностей, тобто - на інклюзивне навчання.

Принагідно зауважимо, що при вирішенні цих завдань у системі інклюзивного навчання одна 3 провідних ролей належить психологічній службі кожного конкретного закладу освіти. Там здійснюється психолого-педагогічний супровід усіх учасників освітнього процесу: дітей і дорослих (фахівців різних напрямів, батьків, адміністрації). Це комплексна система різнобічної, динамічної, корекційної і розвивальної допомоги відповідно до вікових та індивідуальних потреб дітей.

У цьому сенсі саме на психологічний супровід покладаються величезні сподівання - адже йдеться не лише про діагностування, а й про надання системного корекційнореабілітаційного, соціально, психологопедагогічного супроводу кожній дитині незалежно від закладу освіти і форми навчання, а також про систему методичної допомоги ії родині (Засенко, Прохоренко, 2018).

Розглядаючи моделі сприяння дітям із особливими потребами в контексті інклюзивної практики, хотілося 6 зосередитися на стратегіях реалізації психологічного супроводу дітей із особливими освітніми потребами з позицій психологічних, педагогічних, організаційно-методичних вимог.

Відстеження психолого-педагогічного статусу дітей з особливими потребами є досить складним процесом, який потребує тісної співпраці усіх спеціалістів, що беруть участь у їх життєдіяльності. I лише на основі цілісного бачення розвитку

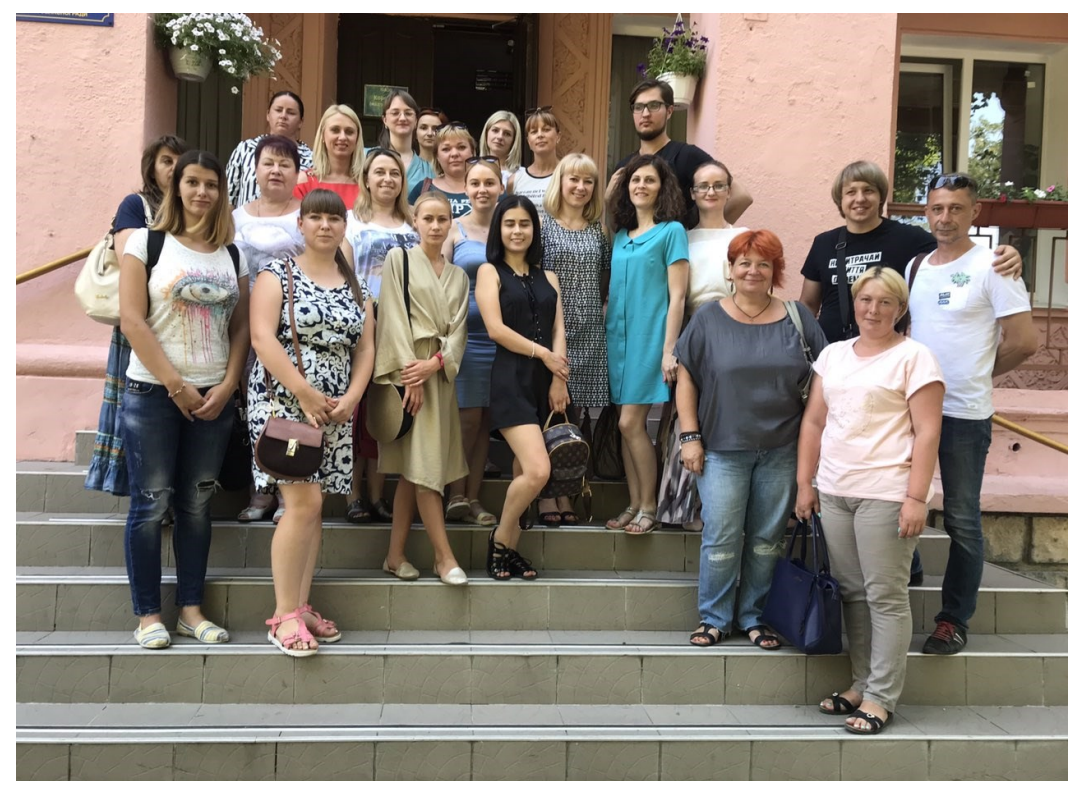
кожної дитини 3 особливими освітніми потребами розробляється і реалізується загальна стратегія навчання та розвитку.

Метою психологічного супроводу $\epsilon$ вивчення особистісного потенціалу дитини, а саме: співвідношення рівня інтелектуального розвитку і вікової норми, розвитку когнітивної сфери, сформованості мотивації до навчання, індивідуальнохарактерологічних особливостей тощо, що насамперед передбачає залучення усіх учасників навчальновиховного процесу (батьків, педагогів, дітей) до реалізації запланованих дій. Серед основних напря- 
мів роботи, окрім вивчення психічного розвитку дитини, - виявлення труднощів у навчанні, спілкуванні та соціальній адаптації, визначення резервів розвитку, з урахуванням яких і розробляються шляхи корекційно-розвивальної роботи тощо (Засенко, Прохоренко, 2018; МОН України, 2018)

3 огляду на зазначене вище, хотілося 6 виокремити основні етапи психолого-педагогічного супроводу дітей з особливими освітніми потребами, а саме: підготовчий, орієнтовний, етап уточнення проблеми, планування, реалізації індивідуальної програми та підсумковий.

Підготовчий eman містить: організацію діяльності мультидисциплінарної команди фахівців; встановлення контакту між усіма учасниками супроводу дитини; визначення обсягу роботи та послідовності процесу психологопедагогічного супроводу; підготовку необхідної документації і складання графіку роботи.

Орієнтовний eman передбачає встановлення контакту: з родиною дитини; $з$ дитиною; $з$ класом, в якому навчається дитина; 3 класним керівником.

Eman уточнення проблеми охоплює: проведення поглибленої психодіагностики; комплексну психолого-педагогічну оцінку розвитку дитини та навчальних вмінь; ознайомлення фахівців із результатами психологічного обстеження; обговорення проблем розвитку дитини та труднощів у навчанні й соціалізації.

Наступний етап - це планування, який містить: розроблення індивідуальної програми розвитку дитини з особливими потребами; затвердження цієї програми усіма спеціалістами, які працюють з дитиною.

Eman реалізації індивідуальної програми поєднує такі завдання: надання необхідної допомоги дитині та педагогам щодо створення умов, необхідних особі з особливими освітніми потребами для ії повноцінної соціалізації і успішного оволодіння навчальними програмами 3 урахуванням психофізичних можливостей; надання необхідної психологічної допомоги родині дитини для гармонізації міжособистісних стосунків та оптимізації виховного процесу; просвітницьку і консультативну роботу з педагогами, педагогами-дефектологами, логопедами, асистентами вчителя та іншими спеціалістами, які працюють $з$ дитиною.

I підсумковий eman зосереджений на колективному обговоренні ефективності проведеної

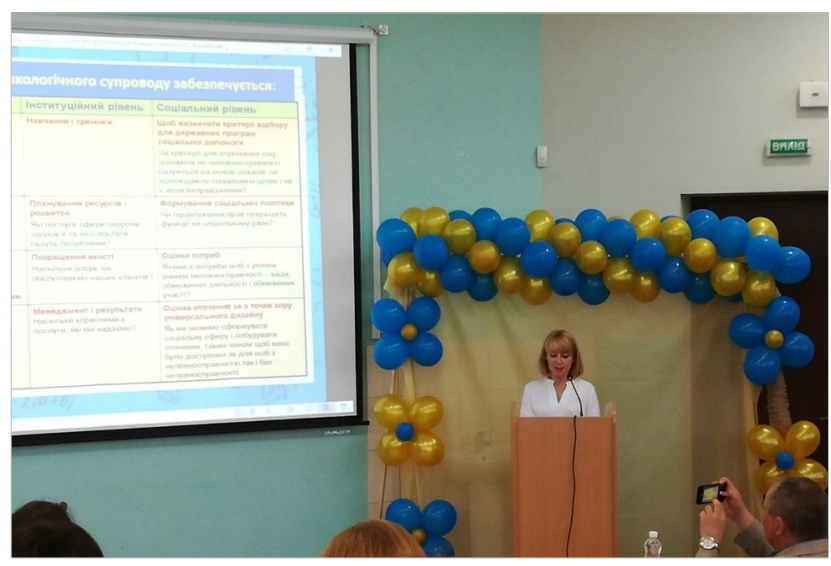

роботи з рекомендаціями щодо подальшого навчання та розвитку кожної дитини з особливими освітніми потребами.

Тобто психологічний супровід дітей із особливими потребами для створення умов їхнього розвитку здійснюється через виконання основних видів діяльності: діагностика, корекція, консультування, просвітництво, допомога (Засенко, Прохоренко, 2018; Drabble, 2013). Зупинимося докладніше на кожному з них.

Діагностична робота містить первинне обстеження, а також систематичні етапні спостереження за динамікою і процесом корекції психічного розвитку дитини. Обгрунтування отриманих результатів обстеження усіма спеціалістами психолого-педагогічного супроводу дає змогу виробити єдине уявлення про характер і особливості розвитку дитини. Здійснюється загальний прогноз ії подальшого розвитку та визначається комплекс необхідних корекційно-розвивальних заходів, що забезпечуватиме в подальшому розроблення індивідуального маршруту розвитку дитини.

Слід додати, що психологічне обстеження не переслідує мети постановки клінічного діагнозу, а спрямоване на кваліфікацію індивідуальних труднощів дитини, якісну характеристику ії розвитку, визначення оптимальних форм і змісту корекційної допомоги, тобто спрямоване на встановлення функціонального діагнозу. Зокрема, визначення «актуального рівня розвитку дитини», зони «найближчого розвитку», виявлення особливостей емоційно-вольової сфери, особистісних характеристик дитини, особливостей ії міжособистісної взаємодії з однолітками, родиною та іншими дорослими.

Відповідно до особливостей розвитку дитини визначають напрями та засоби корекційнорозвивальної роботи, періодичність і тривалість циклу корекційних занять та ін. У корекційній 
роботі найбільш важливим завданням є розроблення індивідуальної програми розвитку дитини згідно 3 індивідуальними особливостями ії психічного розвитку. При цьому важливо врахувати принципи будови, розвитку та реабілітації вищих психічних функцій дітей із особливими освітніми потребами. Наприклад, плануючи роботу щодо корекції затримки психічного розвитку дитини, доцільно розпочинати саме 3 рухових методів на розвиток сенсомоторики, які не лише закладуть потенціал для подальшої роботи, а й сприятимуть активізації і взаємодії між різними рівнями психічної діяльності.

До основних завдань корекційнорозвивальної роботи в системі психологічного супроводу відносять:

- розвиток емоційно-особистісної сфери та корекцію ії порушень (гармонізацію афективної сфери дитини; профілактику та усунення можливих агресивних і негативних проявів, інших відхилень у поведінці; запобігання і подолання негативних рис особистості та формування характеру; розвиток і тренування механізмів, що забезпечують адаптацію дитини до нових соціальних умов; створення умов для формування адекватної самооцінки; розвиток соціальних емоцій, комунікативних здібностей та ін. Водночас робота з розширення емоційного досвіду передбачає допомогу в засвоєнні дитиною уявлень про невербальні засоби вираження емоцій, формування розуміння змісту і значення різних форм поведінки людей в оточенні у емоційно значущих ситуаціях, оцінку дитиною власної поведінки на підставі отриманих знань і навичок);

- розвиток пізнавальної діяльності та цілеспрямоване формування вищих психічних функцій (стимуляція пізнавальної активності як засобу формування пізнавальної мотивації; розвиток уваги (стійкості, концентрації, підвищення об'єму,

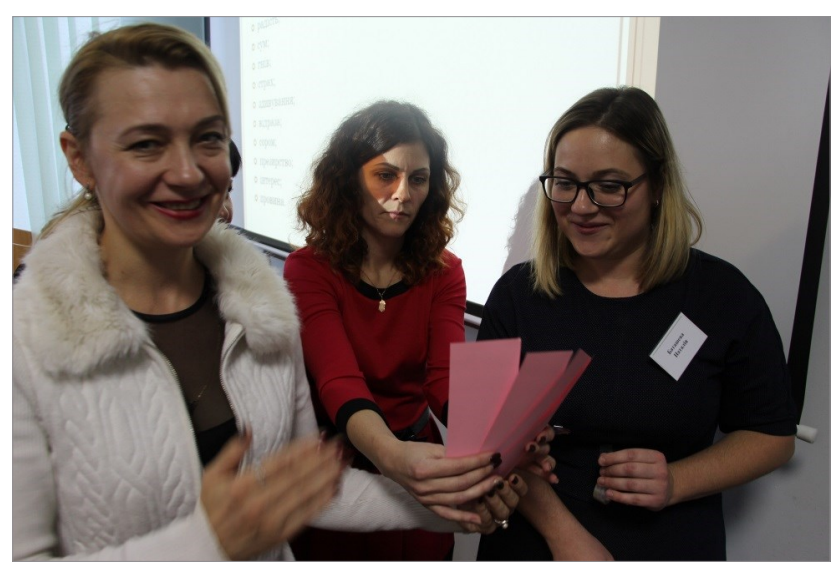

переключення); розвиток пам'яті (розширення обсягу, стійкості, формування прийомів запам'ятовування й ін.); розвиток сприймання (просторового, слухового), просторових і часових уявлень, сенсомоторної координації; формування розумової діяльності (аналізу, порівняння, узагальнення, виділення істотних ознак і закономірностей); розвиток елементарних умовиводів гнучкості розумових процесів);

- формування довільної регуляції діяльності та поведінки (вмінь ставити та утримувати мету діяльності; планувати дії; визначати і зберігати спосіб дій; самоконтролю, оцінювання та самооцінювання процесу і результату діяльності).

Невід'ємним елементом психологічного супроводу $\epsilon$ консультативно-просвітницька профілактична робота, яка передбачає надання педагогам і батькам допомоги у вихованні та розвитку дитини з особливими освітніми потребами і містить такі завдання:

- психологічну підтримку педагогів (розкриття «слабких» і «сильних» сторін когнітивного і особистісного розвитку дитини; визначення шляхів подолання труднощів у навчанні та соціалізації; вироблення найбільш адекватних способів взаємодії з такими дітьми та ін.);

- психологічну підтримку

батьків (встановлення довірчих відносин з родиною, психологічну підтримку батькам, сприяння в усвідомленні особливостей їхніх дітей та необхідності об'єднання зусиль фахівців і родини у їх подоланні, залучення батьків до корекційнорозвивальної роботи, рекомендації щодо подолання можливих проблем та ін.) (Засенко, Прохоренко, 2018; Василькова, Родигіна, Гринчук, та ін., 2006).

Важливо наголосити, що однією з умов залучення дитини до інклюзивного навчання $є$ здатність батьків свідомо сприймати стан дитини, уміти співпрацювати з педагогами, виступаючи їхніми активними помічниками, бути добре обізнаними з перевагами і недоліками різних форм навчання, щоб зробити свідомий вибір компетентно брати участь у навчанні та розвитку.

Варто додати, що створюючи модель системи психолого-педагогічного супроводу, слід дотри муватися таких методологічних вимог, як концептуальність, керованість, ефективність і відтворюваність.

Концептуальність системи психологопедагогічного супроводу припускає опору на наукову концепцію. Система супроводу має 
містити всі ознаки системи (логіку процесу, взаємозв' язок його частин, цілісність).

Керованість системи психолого-педагогічного супроводу передбачає можливість діагностичного цілепокладання, планування, проєктування процесу супроводу, поетапної діагностики, варіювання засобів і методів з метою корекції результатів.

Ефективність системи психолого-педагогічного супроводу свідчить про те, що вона має існувати у конкурентних умовах, тобто гарантувати досягнення прогнозованого результату й бути ефективною за кінцевими результатами.

Відтворюваність - система психологопедагогічного супроводу має бути ефективною для впровадження її в освітній процес для інших категорій дітей.

Отже, функціональність психологопедагогічного супроводу забезпечується комплексом взаємозв'язаних і взаємообумовлених психологічних впливів: діагностичнопрогностичних, організаційно-методичних, корекційно-розвивальних, консультативних, просвітницько-профілактичних. До основних компонентів системи психолого-педагогічного супроводу відносять: мету, завдання, принципи, зміст і етапи, методи й результат. Така система містить впорядковану сукупність дій, операцій і процедур, які інструментально забезпечують досягнення прогнозованого результату.

Результативність системи психологопедагогічного супроводу дітей $з$ особливими потребами полягає у тому, що під час проєктування теоретичної моделі супроводу необхідно: здійснити психологічну діагностику та аналіз динаміки психічного, розумового і соціального розвитку дитини; виявити причини труднощів у навчанні, інтелектуальному та психосоціальному розвитку, соціально-психологічній адаптації; усунути виявлені труднощі психосоціального розвитку дітей, знизити ризики проблем адаптації до освітнього середовища; своєчасно запобігти відхиленням у розвитку та становленні особистості, міжособистісних стосунках, конфліктним ситуаціям у процесі взаємодії; формувати активне співробітництво у навчальній діяльності, що спрямоване на вдосконалення особистості дитини; формувати соціальну компетентність учасників супроводу.

Таким чином, психолого-педагогічний супровід дітей із особливими освітніми потребами має містити комплекс заходів, спрямованих на оцінку

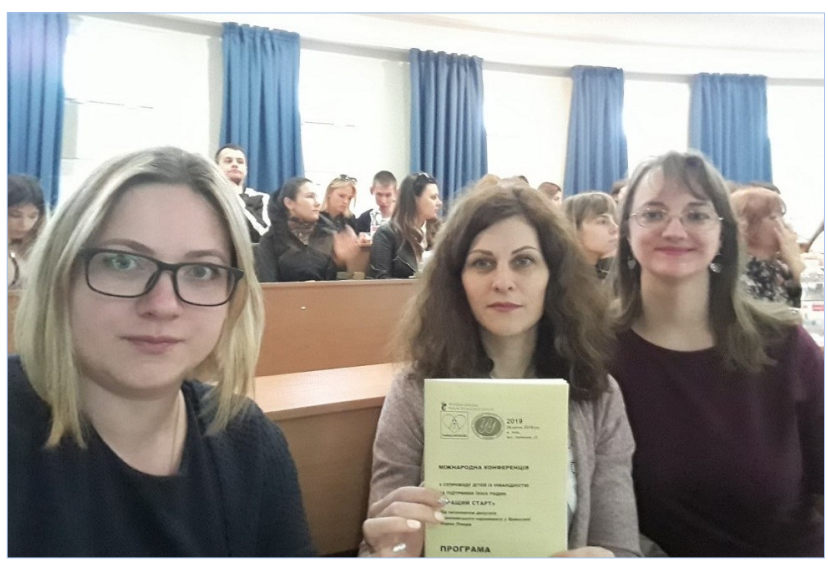

когнітивного розвитку, емоційної, соціальної стійкості, їх готовності до навчальної діяльності, а саме:

- систематичне відстеження клінікопсихологічного та психолого-педагогічного статусу дитини в динаміці ї̈ психічного розвитку (аналіз даних про факти та особливості психічного розвитку дитини, оцінювання умов навчання);

- створення індивідуальних програм психічного розвитку дитини та її навчання;

- створення спеціальних соціальнопсихологічних умов для надання допомоги дітям, які мають проблеми у розвитку, навчанні, поведінці (підвищення здатності до компенсації та адаптації);

- створення соціально-психологічних умов для ефективного психічного розвитку дітей у соціумі;

- систематична психологічна допомога дітям із особливими освітніми потребами та батькам, які виховують таких дітей (консультування, психокорекція, психологічна підтримка);

- організація життєдіяльності дитини в соціумі з урахуванням їі психічних і фізичних можливостей.

У підсумку хотілося $б$ зазначити, що на нашу думку, психологічний супровід базується не лише на внутрішньому потенціалі дитини, метою якого $€$ визначення конкретної траєкторії їі розвитку, а й на сприянні у виявах самостійності, формуванні спрямованої активності, у запобіганні проблемам особистісного розвитку, вирішенні актуальних завдань навчання і соціалізації, а також має містити розвиток психологічної компетентності суб'єкта супроводу.

\section{СПИСОК ВИКОРИСТАНИХ ДЖЕРЕЛ}

Василькова, О.І., Родигіна, І.В., Гринчук, М.І. та ін. (2006). Система соціального і психологопедагогічного супроводу дітей пільгових категорій : навчально-методичний посібник. Донецьк: ДонІППО. «Витоки». 
Закон України «Про освіту». (2017, 5 вересня). https:// zakon.rada.gov.ua/laws/show/2145-19

Засенко, В.В., \& Прохоренко, Л.І. (2018). Нова українська школа - стратегія розвитку освіти дітей з особливими потребами. In N. Nyczkalo, J. Kunikowski, G. Wiezbicki (Eds), Nauka Edukacja Wychowanie i Praca (pp. 149-258). Warszawa-Siedlce.

Кабінет Міністрів України. (2017, 12 липня). Про затвердження Положення про інклюзивноресурсний центр (545). https://zakon.rada.gov.ua/ laws/show/545-2017-п

Кабінет Міністрів України. (2018, 22 серпня). Деякі питання створення ресурсних центрів підтримки інклюзивної освіти та інклюзивно-ресурсних чентрів (617). https://zakon.rada.gov.ua/laws/ show/617-2018-п
Міністерство освіти і науки України. (2010, 1 жовтня) Про затвердження Концепчії розвитку інклюзивного навчання (912). https://zakon.rada.gov.ua/ rada/show/v0912290-10

Міністерство освіти і науки України. (2018, 8 червня). Про затвердження Примірного положення про команду психолого-педагогічного супроводу дитини з особливими освітніми потребами в закладі загальної середньої та дошкільної освіти (609). https://zakon.rada.gov.ua/rada/show/ v0609729-18

Drabble, S. (2013). Support for Children with Special Educational Needs (SEN). European Union. https:// www.rand.org/pubs/research_reports/RR180.html

\title{
PSYCHOLOGICAL SUPPORT OF CHILDREN WITH SPECIAL EDUCATIONAL NEEDS: IMPLEMENTATION STRATEGY
}

\author{
Lesya Prokhorenko \\ DSc in Psychology, Senior Researcher, Deputy Director for Scientific and Experimental Work, \\ Mykola Yarmachenko Institute of Special Pedagogy and Psychology of the National \\ Academy of Educational Sciences of Ukraine, Kyiv, Ukraine \\ Olha Babiak \\ PhD in Psychology, Head of the Department of Psychological and Pedagogical Support for Children \\ with Special Needs, Mykola Yarmachenko Institute of Special Pedagogy and Psychology of the \\ National Academy of Educational Sciences of Ukraine, Kyiv, Ukraine \\ Nataliia Batasheva \\ PhD in Psychology, Scientific Secretary, Mykola Yarmachenko Institute of Special Pedagogy and \\ Psychology of the National Academy of Educational Sciences of Ukraine, Kyiv, Ukraine
}

\begin{abstract}
The article attempts to reveal the peculiarities of psychological assistance to children with special needs, to identify the components of the effectiveness of psychological support and the main areas of activity that need special attention, the leading of which are the diagnostic, counselling and collection work of such persons in the process of education, socialization, life.

The purpose of the article is to determine the strategy of psychological support for children with special needs and their families and the implementation of specific areas of work.

It is substantiated that psychological support for children with special educational needs is a prolonged, dynamic process, holistic activity of the psychological service of an educational institution, which consists of such interconnected components: systematic psychological assistance to children with special needs in the form of counselling, psychology psychological assistance to parents raising these children; monitoring the psychological, pedagogical and social status of a child in the dynamics of his mental development; organization of life activities of children with special needs in society, taking into account their mental and physical abilities.

An effective solution to these issues is to involve children with special needs in an inclusive educational environment, which provides for the creation of special conditions for its educational needs (organizational, methodological, psychological, pedagogical and correctional development, etc.) for their learning and socialization. Accordingly, the content and components of psychological support are the substantive-organizational basis of psychological and pedagogical work with a child with special educational needs in the process of learning and life, which will allow to ensure the individual progress of each child throughout his life.
\end{abstract}

Keywords: psychology; psychological and pedagogical support; correctional work; counselling; special educational needs.

Дата публікації: 30 квітня 2020 р. 